\title{
Correction to: Implementing 'real' change: a Bourdieusian take on stakeholder reflections from the United Nations Partnership on the Rights of Persons with Disabilities project in Uruguay
}

\author{
Holly Wescott ${ }^{1}$ D $\cdot$ Mac MacLachlan ${ }^{1}$
}

Published online: 13 December 2021

(c) The Author(s) 2021

\section{Correction to: SN Social Sciences https://doi.org/10.1007/s43545-021-00280-w}

The article Implementing 'real' change: a Bourdieusian take on stakeholder reflections from the United Nations Partnership on the Rights of Persons with Disabilities project in Uruguay written by Holly Wescott and Mac MacLachlanwas originally published in volume 1, issue 12, page [1-23] without Open Access. The author decided to opt for Open Choice and to make the article an Open Access publication. Therefore, the copyright of the article has been changed to ()$^{2}$ The Author(s) 2021 and the article is forthwith distributed under the terms of the Creative Commons Attribution 4.0 International License, which permits use, sharing, adaptation, distribution and reproduction in any medium or format, as long as you give appropriate credit to the original author(s) and the source, provide a link to the Creative Commons licence, and indicate if changes were made. The images or other third party material in this article are included in the article's Creative Commons licence, unless indicated otherwise in a credit line to the material. If material is not included in the article's Creative Commons licence and your intended use is not permitted by statutory regulation or exceeds the permitted use, you will need to obtain permission directly from the copyright holder. To view a copy of this licence, visit http://creat ivecommons.org/licenses/by/4.0.

The original article can be found online at https://doi.org/10.1007/s43545-021-00280-w.

Holly Wescott

holly.wescott.2019@mumail.ie; hollywescott@gmail.com

Mac MacLachlan

Mac.MacLachlan@mu.ie

1 Department of Psychology and the Assisting Living \& Learning (ALL) Institute, Maynooth University, Maynooth, Ireland 
Open Access This article is licensed under a Creative Commons Attribution 4.0 International License, which permits use, sharing, adaptation, distribution and reproduction in any medium or format, as long as you give appropriate credit to the original author(s) and the source, provide a link to the Creative Commons licence, and indicate if changes were made. The images or other third party material in this article are included in the article's Creative Commons licence, unless indicated otherwise in a credit line to the material. If material is not included in the article's Creative Commons licence and your intended use is not permitted by statutory regulation or exceeds the permitted use, you will need to obtain permission directly from the copyright holder. To view a copy of this licence, visit http://creativecommons.org/licen ses/by/4.0/. 